\title{
PENGARUH PENGUNGKAPAN ENTERPRISE RISK MANAGEMENT, PENGUNGKAPAN INTELLECTUAL CAPITAL, DAN STRUKTUR PENGELOLAAN PADA NILAI PERUSAHAAN
}

\author{
Ana Dwiyanti Candra ${ }^{1}$ \\ I Dewa Nyoman Wiratmaja ${ }^{2}$
}

Fakultas Ekonomi dan Bisnis, Universitas Udayana, Bali, Indonesia ${ }^{1,2}$

Email: anacandra99@gmail.com / Telp: 08563813899

\begin{abstract}
Firm value considered by investor to make investment decision. Higher firm value influenced the investor's confidence to invest on a firm. Based on the phenomenon and associated theory, firm value influenced by ERMD, ICD, and management structure. This research aims to find out empirical evidence on the ERMD, ICD, and management structure (proxied with independent commissioner proportion). This research conducted at bank firms listed on Indonesia Stock Exchange in 2016-2018. Purposive sampling method used in the sample selection, obtaining 31 banks as the sample with total 93 data during 3 years. There are 7 data outliers excluded from the analysis in order to obtain as many as 86 data. Using MRA, obtained results that only the ERMD variable that positively influenced firm value while the other two independent variables has no effect on firm value.
\end{abstract}

Keywords: Enterprise Risk Management Disclosure; Intellectual Capital Disclosure; Management Structure; Firm Value

\begin{abstract}
ABSTRAK
Nilai perusahaan sangat diperhatikan investor untuk mengambil keputusan investasi. Semakin baik nilai perusahaan, investor semakin percaya untuk berinvestasi. Berdasarkan fenomena dan teori terkait, perusahaan dapat meningkatkan nilai dengan melakukan pengungkapan ERM, pengungkapan IC, dan struktur pengelolaan. Tujuan penelitian ini adalah memberikan bukti empiris pengungkapan ERM, pengungkapan IC, dan struktur pengelolaan mempengaruhi nilai perusahaan. Penelitian ini dilakukan pada perusahaan perbankan di BEI periode 2016-2018. Dengan purposive sampling diperoleh 31 perusahaan sampel dengan total 93 data observasi selama 3 tahun. Sebanyak 7 data outlier dikeluarkan, sehingga diperoleh sebanyak 86 data amatan. Teknik analisis data menggunakan analisis regresi berganda. Berdasarkan hasil pengujian hipotesis, diperoleh hasil bahwa hanya variabel ERMD yang berpengaruh positif ada nilai perusahaan, sedangkan dua variabel independen lainnya tidak mempengaruhi nilai perusahaan.
\end{abstract}

Kata Kunci: Pengungkapan Enterprise Risk Management; Pengungkapan Intellectual Capital; Struktur Pengelolaan; Nilai Perusahaan 


\section{PENDAHULUAN}

Penilaian perusahaan sangat penting karena hal tersebut secara fundamental dapat memberi imbal hasil ekonomis bagi para investor di masa depan. Investor dalam melakukan analisis nilai perusahaan berusaha memproyeksikan pernyataan perusahaan dalam rencana bisnis perusahaan. Tujuan dari analisis nilai perusahaan tersebut untuk memahami dan menghitung nilai riil perusahaan dan rencana bisnis untuk menggambarkan nilai investasi investor (Caselli \& Negri, 2018).

Nilai perusahaan secara global mulai tahun 2016 secara tidak langsung terkena dampak dari adanya kebijakan-kebijakan seperti Brexit di Eropa dan perang dagang yang terjadi antara Amerika Serikat dengan Tiongkok. Keputusan Brexit diyakini dapat menjalar ke perekonomian dunia, termasuk dalam pasar keuangan, pasar modal, hingga pasar komoditi dunia. Bank Indonesia juga menilai bahwa keputusan Brexit dapat berimplikasi jangka panjang. Bank Indonesia juga telah membuat kajian yang berkaitan dengan keputusan Brexit dan menyatakan bahwa pertumbuhan ekonomi Inggris berpotensi menurun sampai 7 persen pada tahun 2030. Brexit diyakini berdampak bagi perekonomian Indonesia dimana dampak tersebut ditandai dengan melemahnya nilai tukar rupiah hingga mencapai 1 persen dan merosotnya Indeks Hargam Saham Gabungan (IHSG) (Setiawan, 2016).

Perang tarif yang terjadi antara Amerika Serikat dan Tiongkok, mengakibatkan industri dalam negeri cenderung melambat dan pelaku industri 
tidak mampu melakukan ekspansi. Hal tersebut tentunya mempengaruhi permintaan kredit pelaku industri ke perusahaan perbankan menurun, sehingga bank sebagai industri yang mengandalkan atau sumber pendapatan utamanya berasal dari bunga kredit pun mengalami perlambatan. Sebagai negara dengan sistem keuangan bank-centered, dimana total aset industri perbankan 55 persen dari Produk Domestik Bruto (PDB) pada tahun 2016, industri perbankan menjadi industri yang sangat penting dan sering mendapat perhatian dari masyarakat ketika terdapat pemberitaan positif maupun negatif mengenai perbankan (World Bank, 2017).

Perbankan merupakan industri vital di Indonesia, karena perbankan menyalurkam dana kepada perusahaan besar atau perorangan sehingga apabila perbankan mengalami collaps dan kehilangan kepercayaan dari publik, pengaruhnya akan sangat besar bahkan dapat membuat perekonomian negara juga ikut collaps. Vitalnya industri perbankan di Indonesia pun ditunjukkan dengan adanya regulasi yang sangat ketat dari pemerintah, teregulasi dalam UndangUndang Republik Indonesia Nomor 10 Tahun 1998 tentang Perbankan.

Terdapat dua pengungkapan dalam laporan tahunan yang telah ditetapkan dalam POJK Nomor 29/POJK.04/2016 tentang Laporan Tahunan Emiten atau Perusahaan Publik dan berdasarkan ketentuan dari Ikatan Akuntan Indonesia, yaitu: (1) pengungkapan wajib (mandatory disclosure) merupakan pengungkapan informasi yang dibuat berdasarkan peraturan pasar modal; dan (2) pengungkapan sukarela (voluntary disclosure) merupakan pengungkapan informasi oleh perusahaan yang dibuat tanpa diharuskan oleh standar yang ada (OJK, 2016). 
Informasi yang dipublikasikan oleh perusahaan dan diterima oleh stakeholders dapat dianggap sebagai berita baik ataupun berita buruk. Informasi tersebut direspon oleh investor di pasar modal dan dapat berakibat pada volatilitas volume perdagangan saham, sehingga menjadi pendukung nilai perusahaan untuk meningkat atau sebaliknya (Morris, 2016) dan (Arifah \& Wirajaya, 2018). Teori sinyal menyatakan bahwa informasi merupakan unsur yang penting bagi investor karena informasi mengandung keterangan, catatan atau gambaran masa lalu, saat ini, maupun masa depan bagi kelangsungan hidup suatu perusahaan dan bagaimana pasaran efeknya (Khumairoh \& Agustina, 2017).

Investor yang hanya berfokus pada informasi finanasial dalam pengambilan keputusan investasi yang di dapat dari laporan keuangan perusahaan, belum mampu menjadi jaminan keuntungan yang dapat diraih oleh investor tersebut. Investor besar yang sangat fenomenal di dunia yaitu Warren Buffet melalui perusahaannya Berkshire Hathway sebagai value creation investor selalu menargetkan perusahaan-perusahaan yang belum terlalu besar namun nilainya diyakini dapat meningkat di masa mendatang untuk menginvestasikan dananya kemudian menghasilkan keuntungan berkali-kali lipat (Lafont et al., 2020). Tidak cukup hanya mengandalkan informasi finansial perusahaan saja, karena banyak kasus yang menunjukkan bahwa informasi finansial yang terus-menerus terlihat baik belum dapat menjamin keberlanjutan usaha perusahaan.

Di Indonesia, terdapat isu-isu yang melibatkan laporan perusahaan mulai dari ketidaktelitian pihak internal perusahaan hingga terjadinya fraud. Otoritas Jasa Keuangan (OJK) mencatat sebanyak kurang lebih 108 kasus tindak pidana 
perbankan selama hampir dua tahun (2014-2016). Anggota Dewan Komisioner OJK pun mengakui terjadinya kompelksitas tinggi pada penyimpangan kegiatan operasional perbankan, dalam hal administratif dan berpotensi terjadi tindak pidana atau fraud (Ariyanti, 2016). PT Bank Bukopin Tbk tersandung kasus rekayasa laporan keuangan pada informasi terkait kartu kredit yang diketahui setelah penyelidikan berlangsung selama bertahun-tahun. Praktik kecurangan itu berakibat pada posisi akun pendapatan bank yang berasal dari bunga kredit dan kredit nasabah bank dalam laporan keuangan tidak semestinya. Bahkan meskipun modifikasi tersebut telah terjadi bertahun-tahun, kecurangan tersebut berhasil mengelabui macam-macam lapisan pengawasan dan audit (Banjarnahor, 2018). Kasus ini menjadi salah satu bukti bahwa Enterprise Risk Management (ERM) perbankan di Indonesia masih lemah dan rawan terjadi kecurangan, serta tidak cukup hanya menilai suatu perusahaan hanya dengan melihat laporan keuangannya saja.

Informasi risiko perusahaan diatur oleh beberapa regulator di Indonesia bahwa informasi tersebut harus dilaporkan perusahaan dalam laporan tahunan. PSAK 60 (Revisi 2010) tentang Instrumen Keuangan: Pengungkapan, dan Keputusan Ketua Bapepam-LK Nomor KEP 431/BL/2012 tentang Penyampaian Laporan Tahunan Emiten atau Perusahaan Publik, menyebutkan bahwa informasi yang dapat digunakan oleh pengguna laporan keuangan untuk mengevaluasi jenis dan tingkat risiko dari instrumen keuangan harus diungkapkan. Berdasarkan kedua aturan tersebut, seluruh perusahaan keuangan dan nonkeuangan diwajibkan untuk menyampaikan informasi risiko dalam laporan tahunan, tetapi luas 
pengungkapan minimum tentang manajemen risiko tidak diatur dalam kedua ketentuan tersebut (Devi dkk., 2017). Perbankan sebagai industri yang vital dan berisiko tinggi, diatur ketat dalam hal pelaporan dan pengungkapan dalam laporan perusahaan. POJK Nomor 18/POJK.03/2016 tentang Penerapan Manajemen Risiko bagi Bank Umum menyebutkan bahwa perusahaan keuangan diwajibkan untuk membentuk komite manajemen risiko dan satuan kerja manajemen risiko seperti yang dicantumkan pada Pasal 16 huruf (a) dan (b) dalam peraturan tersebut. Bank umum yang berbentuk syariah juga diwajibkan membentuk manajemen risiko dan satuan kerja manajemen risiko berdasarkan POJK Nomor 65/POJK.03/2016 tentang Penerapan Manajemen Risiko bagi Bank Umum Syariah dan Unit Usaha Syariah Pasal 18 Ayat (1). Pengungkapan manajemen risiko (ERMD) bagi perusahaan perbankan termasuk ke dalam mandatory disclosure, yang mana telah menjadi suatu keharusan bagi setiap perusahaan perbankan untuk mengungkapkan informasi mengenai risiko manajemen perusahaan dalam laporan tahunannya. Namun dalam penelitian ini, pengungkapan manajemen risiko yang ingin diselidiki adalah pengungkapan manajemen risiko perusahaan yang diterbitkan oleh COSO karena framework pengungkapan manajemen risiko perusahaan yang diterbitkan oleh COSO telah diterapkan oleh banyak perusahaan secara global.

ERMD merupakan salah satu faktor yang dapat mempengaruhi nilai perusahaan karena ERMD mengandung informasi pengelolaan risiko yang dilakukan oleh perusahaan dan mengungkapkan dampaknya bagi masa depan perusahaan (Hoyt dan Liebenberg, 2011). Setiap perusahaan pasti memiliki 
risikonya masing-masing, tergantung dari karakteristik usahanya. Pengungkapan risiko dalam laporan perusahaan juga terdapat dalam standar akuntansi seperti IFRS Nomor 7 tentang Risk Disclosure (Jubb, 2016). Beberapa penelitian pun membuktikan bahwa ERMD dalam laporan perusahaan berpengaruh positif pada nilai perusahaan, sejalan dengan penelitian (Bertinetti et al., 2013), (Abdel-azim \& Abdelmoniem, 2015), (Abdullah et al., 2015), dan (Devi dkk., 2017). Semakin banyak, kompleks, dan lengkap item yang disajikan oleh perusahaan tentang manajemen risiko perusahaan dalam laporan tahunan atau annual report, maka dapat menjadi stimulus pada peningkatan nilai perusahaan dan mengirimkan sinyal positif kepada investor. Selain itu, manajemen risiko yang tepat yang disajikan dalam annual report perusahaan dapat memberi sinyal baik bagi investor untuk mengambil keputusan investasi. Terdapat beberapa faktor yang mendukung implementasi ERM dan ERMD dapat diterima di negara seperti Kanada dan di dunia (Maingot et al., 2013). Pertama, perusahaan mulai menyadari adanya masalah dalam perusahaan termasuk juga krisis finansial. Direksi dan eksekutif perusahaan menyadari konsekuensi adanya ketidakefektifan manajemen risiko dalam perusahaan. Kedua, adanya persyaratan dari regulator yang mempengaruhi ERMD di Kanada, yaitu Canadian Institute of Chartered Accountants (CICA), International Accounting Standards Board (IASB), Canadian Securities Administrators (CSA), Financial Accounting Standards Board (FASB), Securities Exchange Commission (SEC), Basel II, Basel III, Toronto Stock Exchange (TSX), dan juga New York Stock Exchange (NYSE). Faktor ketiga adalah jumlah inisiatif secara global dalam corporate governance 
dan manajemen risiko. United Kingdom (UK) mengawali dengan mempublikasikan Cadburry Report tahun 1992, dan kemudian sejumlah intervening reports sebelum publikasi Combined Codes. Barulah kemudian COSO pada tahun 2004 mempublikasikan kerangka incorporating corporate governance dan internal kontrol sebagai bagian utuh dari struktur ERM (Maingot et al., 2013).

Arifah dan Wirajaya, (2018) menemuan pengaruh ERMD negarif pada nilai perusahaan, meningkatnya ERMD di laporan tahunan justru menjadi berita buruk bagi investor karena justru memberi gambaran buruk mengenai manajemen perusahaan dalam menanggulangi risiko yang mungkin terjadi dan risiko tersebut dianggap dapat mengganggu tujuan investor. Namun Agustina dan Baroroh, (2016), Ardianto dan Rivandi, (2018), Mariani dan Suryani, (2018), Siregar dan Safitri, (2019) tidak menemukan adanya pengaruh dari ERMD pada nilai perusahaan yang diteliti. Koeswara dan Harjito, (2016) mengungkapkan bahwa investor di Indonesia lebih mengapresiasi perusahaan yang memiliki profitabilitas yang tinggi dan leverage yang rendah, penerapan ERM di Indonesia masih dalam tahap adopsi, sehingga investor kurang memperhatikan penerapan ERM. Dari penjelasan tersebut, peneliti mengajukan hipotesis:

$\mathrm{H}_{1}$ : Pengungkapan enterprise risk mangement berpengaruh positif pada nilai perusahaan perbankan.

Selain ERMD, perusahaan juga dipercaya dapat dapat menigkatkan nilai perusahaan dengan mengungkapkan intellectual capital (ICD) dalam annual 
report. ICD merupakan pengungkapan informasi mengenai segala hal yang diketahui oleh semua pihak di dalam perusahaan yang dapat meningkatkan daya saing perusahaan. IC meliputi intellectual material, pengetahuan, pengalaman, intellectual property, dan informasi yang bermanfaat dalam menciptakan nilai (Dumay, 2016). ICD dalam laporan tahunan yang dipublikasikan terbukti memberi pengaruh dalam meningkatkan kualitas pengambilan keputusan oleh investor dan membantu mendisiplinkan manajemen dan dewan direksi perusahaan dengan dampak ekonomi yang positif. Kekonsistenan informasi nonfinansial yang dapat dijadikan perbandingan antarperiode (waktu) laporan dan perbandingan dengan industri yang sejenis (across companies) secara material dan informasinya dapat diandalkan (reliable) akan membuat investor dapat memperkirakan pendapatannya di masa depan (Devi dkk., 2017). Penelitian tersebut didukung oleh penelitian Ardianto dan Rivandi, (2018) yang membuktikan bahwa ICD dapat memberikan sinyal positif (good signal) kepada investor untuk mengambil keputusan investasi. Pengungkapan secara sukarela dengan ICD relevan untuk diterapkan dan ditekankan bahwa pengungkapan ini dapat mempengaruhi nilai dan reputasi dari suatu organisasi (Dumay \& Guthrie, 2017).

Terdapat beberapa penelitian yang kontra dengan pernyataan yang menyatakan ICD dapat meningkatkan nilai perusahaan, karena manajer memahami bahwa kekuatan dalam membuat IC dapat menciptakan suatu nilai adalah dengan tidak mengungkapkannya dalam laporan tahunan yang dipublikasikan. Jika ditinjau dari resource-based view (RBV) yang menyatakan bahwa sumber daya tidak berwujud (intangible resource) adalah yang paling 
bernilai dalam keunggulan kompetitif (competitive advantage) (Dierickx \& Cool, 1989) dalam (Dumay, 2016). Maka dari itu manajemen memandang bahwa pengungkapan IC dalam annual report justru menguntungkan kompetitor perusahaan (Dumay, 2016). Dalam penelitian (Giacosa et al., 2017) dikatakan manajer perusahaan lebih mementingkan informasi manajemen intellectual capital hanya untuk pihak internal perusahaan, bukan untuk menarik perhatian investor potensial. IC mulai berkembang di Indonesia setelah munculnya PSAK 19 (Revisi 2000) tentang Aktiva Tidak Berwujud. PSAK 19 mendefinisikan aset tidak berwujud perusahaan sebagai aset nonmoneter teridentifikasi tanpa wujud fisik, perusahaan berpotensi memperoleh manfaat ekonomi massa depan dari aset tersebut dan biaya perolehan aset tersebut dapat diukut secara andal (Lestari, 2013). Maka dari itu, ERMD dan ICD dapat dikategorikan sebagai dua hal baru dalam pasar modal. Dari penjelasan tersebut, peneliti mengajukan hipotesis:

$\mathrm{H}_{2}$ : Pengungkapan intellectual capital berpengaruh positif pada nilai perusahaan perbankan.

Hafiyyan (2018), nilai perusahaan lebih dipengaruhi oleh manajemen puncak dari pada ukuran perusahaan. Negara, (2019) menyimpulkan bahwa proporsi dewan komisaris independen (DKI) dalam dewan komisaris sangat tepat untuk dijadikan proksi dari struktur pengelolaan perusahaan untuk mengetahui pengaruh struktur pengelolaan pada nilai perusahaan. Nilai perusahaan dipengaruhi oleh Good Corporate Governance (GCG) yang dapat diproksikan dengan dewan proporsi DKI (Syafitri dkk., 2018) dan (Cyntia \& Tambunan, 2017). Dewan komisaris adalah organ perseroan yang bertugas melakukan 
pengawasan secara umum dan khusus sesuai dengan anggaran dasar serta memberi nasihat kepada direksi.

Susunan dewan komisaris dan DKI, apabila jumlah dewan komisaris terdiri dari dua orang anggota dewan komisaris dengan satu diantaranya harus dari pihak independen. Sedangkan, pada perusahaan yang memiliki jumlah dewan komisaris lebih dari dua orang, maka persentase jumlah DKI sekurang-kurangnya sebanyak 30 persen dari total dewan komisaris perusahaan. Syarat untuk menjadi seorang DKI yang telah diatur dalam POJK No. 33 Tahun 2014, salah satu syarat tersebut adalah bukan merupakan orang yang bekerja atau mempunya wewenang dan tanggung jawab untuk merencanakan, memimpin, mengendalikan, atau mengawasi kegiatan perusahaan publik tersebut dalam waktu enam bulan (OJK, 2014).

Menurut survei tahun 2016, pelaku kejahatan fraud dari segi jabatan, fraud paling banyak dilakukan dari jabatan manajer yaitu sebanyak 40,3 persen, kemudian atasan atau pemilik sebanuak 30,7 persen, karyawan sebanyak 22,9 persen, dan lainnya sebanyak 6,1 persen (ACFE, 2017). Bahkan survei fraud secara global menemukan bahwa industri yang paling banyak ditemukan pada industri perbankan dan jasa keuangan yaitu sebanyak 338 kasus dan kasus yang paling banyak adalah korupsi di internal perbankan dan jasa keuangan dengan persentase 36 persen.

Penelitian Sadasiha, (2014) menyimpulkan bahwa DKI berpengaruh positif pada nilai perusahaan. Semakin besar persentase DKI dapat meningkatkan 
keyakinan investor terhadap struktur pengelola perusahaan berjalan sesuai dengan aturan yang telah ditetapkan dalam Rapat Umum Pemegang Saham dan peraturan regulator terkait, sehingga berkontribusi menciptakan nilai tambah bagi perusahaan. Marhaeni dan Yanto, (2015) menyatakan bahwa keberadaan dewan komisaris, khususnya anggota DKI memberikan pengaruh dalam mengurangi biaya pinjaman (cost of debt) karena DKI bukan merupakan pegawai dan lebih independen, sehingga dapat meningkatkan kualitas pengawasan dan monitoring. Penelitian tersebut sejalan dengan Hariati dan Widya, (2013), Muryati dan Suardikha, (2014), Alfinur, (2016), Cyntia dan Tambunan, (2017), dan Handayani, (2017). Berbeda dengan Yopie dan Jurnali, (2014) dan Ardianto dan Rivandi, (2018) yang justru menemukan adanya pengaruh negatif dari banyaknya DKI pada nilai perusahaan. Penelitian Rahmi dan Harnovinsah, (2013), Kumar, (2013), Wulandari dan Budiartha, (2014), dan Aprianingsih, (2016) membuktikan bahwa tidak ada pengaruh dari proporsi DKI berpengaruh pada nilai perusahaan. Dari penjelasan tersebut, peneliti mengajukan hipotesis:

$\mathrm{H}_{3}$ : Pengungkapan dewan komisaris independen berpengaruh positif pada nilai perusahaan.

\section{METODE PENELITIAN}

Penelitian ini berlokasi di Bursa Efek Indonesia dengan populasi penelitian sebanyak 45 bank dalam periode amatan 2016-2018. Objek penelitian adalah nilai perusahaan, ERMD, ICD, dan struktur pengelolaan. Purposive sampling diterapkan sebagai teknik penyampelan dengan kriteria perusahaan 
perbankan tercatat di BEI, mempublikasikan annual report berturut-turut selama periode amatan, tidak melakukan aksi korporasi merger yang menyebabkan perusahaan sampel melebur dan membuat informasi dalam laporan berubah drastis, serta perusahaan tidak mengalami kerugian karena perusahaan yang merugi berarti tidak menerapkan manajemen risiko yang baik sehingga mengalami kerugian. Jenis data yang digunakan dalam penelitian ini adalah data kuantitatif, yaitu dengan laporan tahunan perusahaan yang merupakan data sekunder. Data penelitian ini dikumpulkan dengan cara obersvasi nonpartisipan. Variabel independen dalam penelitian ini adalah ERMD $\left(\mathrm{X}_{1}\right)$, ICD $\left(\mathrm{X}_{2}\right)$, dan struktur pengelolaan yang diproksikan dengan proporsi DKI $\left(\mathrm{X}_{3}\right)$. Variabel dependen dalam penelitian ini adalah nilai perusahaan (Y).

Nilai perusahaan perbankan dapat diukur dengan rasio Tobin's $Q$ yaitu nilai pasar yang mampu memberikan kemakmuran bagi pemegang saham secara maksimum jika harga saham perusahaan meningkat (Cyntia \& Tambunan, 2017). Rasio Tobin's $Q$ merupakan alat ukur yang akurat, dapat memberi gambaran kuantitatif keefektifan pihak manajemen dalam pengelolaan sumber daya yang dimiliki perusahaan (Damayanthi, 2019). Dalam perhitungan Tobin's $Q$ semua unsur hutang dan modal saham perusahaan dihitung sehingga rasio ini dinilai dapat memberikan informasi paling baik.

Rumus perhitungan skor Tobin's $Q$ :

$\mathrm{Q}=\underline{\mathrm{MVS}+\mathrm{D}}$

TA 
Keterangan:

Tobin's $Q \quad$ : Indikator penilaian perusahaan

MVS : Nilai pasar saham (market value of all outstanding shares) yang diperoleh dari hasil perkalian jumlah saham yang beredar dengan harga saham (outstanding share $\times$ stock price)

D : Total nilai buku dari hutang perusahaan

TA : Total aset perusahaan

Berdasarkan ERM framework yang dikeluarkan COSO terdapat 108 item pengungkapan ERM yang mencakup delapan dimensi. Delapan dimensi tersebut yaitu: 1) lingkungan internal; 2) penetapan tujuan; 3) identifikasi kejadian; 4) penilaian risiko; 5) respon atas risiko; 6) kegiatan pengawasan; 7) informasi dan komunikasi; dan 8) pemantauan. Rumus menghitung pengungkapan ERM (Devi dkk., 2017):

$\mathrm{ERMD}=\Sigma \mathrm{ERMDitem}$

Keterangan:

ERMD $\quad$ : Enterprise Risk Management Disclosure

¿ERMDitem : Total item ERMD yang diungkapkan

ICD adalah jumlah pengungkapan informasi tentang IC yang disajikan dalam laporan tahunan perusahaan (Ulum, 2015). ICD diproksikan dengan indeks ICD sesuai dengan dimensi ICD yang digunakan (White et al., 2010). Indeks tersebut terdiri dari 78 item yang diklasifikasikan ke dalam enam kategori yaitu: 
1) karyawan; 2) pelanggan; 3) teknologi informasi; 4) proses; 5) riset dan pengembangan; dan 6) pernyataan strategis. Rumus menghitung ICD:

$\mathrm{ICD}=\Sigma \mathrm{ICD}$ item

Keterangan:

ICD : Intellectual Capital Disclosure

IICDitem : Total item ICD yang diungkapkan

Dewan komisaris independen merupakan anggota dewan komisaris perusahaan yang berasal dari luar perusahaan publik dan memenuhi persyaratan sebagai DKI (OJK 2014). Rumus menghitung DKI:

$\mathrm{DKI}=\underline{\Sigma \mathrm{DKI}}$

$\Sigma \mathrm{DK}$

Keterangan:

DKI : Proporsi persentase dewan komisaris independen

¿DKI : Jumlah dewan komisaris independen

$\Sigma$ DK : Total dewan komisaris

\section{HASIL DAN PEMBAHASAN}

Penelitian ini dilakukan untuk mengetahui pengaruh pengungkapan ERM, pengungkapan IC, dan struktur pengelolaan pada nilai perusahaan. Sampel yang digunakan dalam penelitian ini dipilih sesuai dengan kriteria yang telah ditentukan atau purposive sampling, agar sampel yang digunakan mampu menjelaskan 
populasi serta sesuai dengan tujuan penelitian. Berdasarkan penentuan kriteria pemilihan sampel data sekunder tersebut, diperoleh hasil pada Tabel 1.

Tabel 1.

\section{Proses Pemilihan Sampel}

\begin{tabular}{lc}
\hline \multicolumn{1}{c}{ Kriteria } & $\begin{array}{c}\text { Jumlah } \\
\text { Perusahaan }\end{array}$ \\
\hline Perusahaan subsektor perbankan yang terdaftar di BEI tahun $2016-$ & 45 \\
2018 & $(2)$ \\
Perusahaan melakukan merger atau delisted dari BEI tahun $2016-2018$ & $(12)$ \\
Perusahaan perbankan mengalami kerugian 2016-2018 & 31 \\
Total perusahaan sampel & 3 \\
Tahun pengamatan & $(7)$ \\
Data outlier & 86 \\
\hline Total sampel pengamatan & 86 \\
\hline
\end{tabular}

Perusahaan subsektor perbankan yang terdaftar di BEI selama periode 2016-2018 merupakan lokasi dalam penelitian ini dan diperoleh dengan mengakses situs resmi BEI yaitu www.idx.co.id. Berdasarkan Tabel 1 tersebut, terdapat 86 data sampel amatan yang layak untuk digunakan dalam penelitian setelah dikeluarkan 7 data outlier.

Uji asumsi klasik yang digunakan sebagai uji kelayakan model sebelum dilakukan analisis regresi linear berganda yaitu dengan uji normalitas, uji multikolinearitas, serta uji heteroskedastisitas. Hasil uji normalitas sampel pada penelitian ini menunjukkan bahwa nilai Asymp. Sig. (2-tailed) sebesar 0,064, lebih besar dari level of significant, yaitu sebesar 5 persen atau 0,05 sehingga dapat diartikan bahwa data berdistribusi normal. Hasil uji multikolinearitas menunjukkan nilai VIF untuk masing-masing variabel bebas adalah lebih kecil 
dari 10 dan nilai tolerance untuk masing-masing variabel independen yang diuji dalam penelitian ini memiliki nilai signifikan lebih dari 0,05 . Oleh karena itu model regresi yang digunakan dalam penelitian ini tidak mengalami gejala heteroskedastisitas.

Analisis regresi berganda dilakukan untuk mengetahui pengaruh dari ERMD $\left(\mathrm{X}_{1}\right)$, ICD $\left(\mathrm{X}_{2}\right)$, dan persentase dewan komisaris independen $\left(\mathrm{X}_{3}\right)$ pada nilai perusahaan (Y) yang tercatat di BEI 2016-2018. Hasil dari analisis regresi linear berganda dapat dilihat pada Tabel 2 .

Tabel 2.

Hasil Analisis Linear Berganda

\begin{tabular}{|c|c|c|c|c|c|c|}
\hline & \multirow[b]{2}{*}{ Model } & \multicolumn{2}{|c|}{$\begin{array}{c}\text { Umstandardized } \\
\text { Coefficients }\end{array}$} & \multirow{2}{*}{$\begin{array}{c}\begin{array}{c}\text { Standardized } \\
\text { Coefficient }\end{array} \\
\text { Beta }\end{array}$} & \multirow[b]{2}{*}{$\mathbf{t}$} & \multirow[b]{2}{*}{ Sig. } \\
\hline & & B & $\begin{array}{c}\text { Std. } \\
\text { Error }\end{array}$ & & & \\
\hline \multirow[t]{4}{*}{1} & (Constant) & ,646 &, 083 & & 7,744 &, 000 \\
\hline & $\operatorname{ERMD}\left(\mathrm{X}_{1}\right)$ & ,003 & 001 & ,448 & 3,209 &, 002 \\
\hline & $\operatorname{ICD}\left(\mathrm{X}_{2}\right)$ &,- 001 & 001 &,- 144 & $-1,063$ & ,291 \\
\hline & $\operatorname{DKI}\left(\mathrm{X}_{3}\right)$ & 078 & 076 &, 112 & 1,027 & ,307 \\
\hline \multicolumn{4}{|c|}{ a. Dependent Variabe: Nilai Perusahaan (Y) } & & & \\
\hline
\end{tabular}

Sumber: Data Penelitian, 2020

Berdasarkan hasil analisis regresi linear berganda pada Tabel 2, maka dapat dibuat persamaan sebagai berikut:

$Y=0,646+0,003 X_{1}-0,001 X_{2}+0,078 X_{3}$

Keterangan:

Y: Nilai perusahaan

$\mathrm{X}_{1}$ : Pengungkan Enterprise Risk Management

$\mathrm{X}_{2}$ : Pengungkapan Intellectual Capital

$\mathrm{X}_{3}$ : Proporsi dewan komisaris independen 
Nilai konstanta sebesar 0,646 menunjukkan bahwa apabila pengungkapan enterprise risk management, pengungkapan intellectual capital, dan struktur pengelolaan sama dengan nol, maka besarnya nilai perusahaan adalah 0,646 dengan asumsi variabel lainnya adalah konstan. Nilai koefisien $\beta_{1}=0,003$ menunjukkan bahwa pengungkapan enterprise risk management berpengaruh positif pada nilai perusahaan subsektor perbankan yang terdaftar di BEI, yaitu jika pengungkapan enterprise risk management meningkat atau bertambah satu satuan maka akan meningkatkan nilai perusahaan sebesar 0,003 dengan asumsi variabel lainnya konstan. Nilai koefisien $\beta_{2}=-0,001$ menunjukkan bahwa pengungkapan intellectual capital berpengaruh negatif pada nilai perusahan subsektor perbankan yang terdaftar di BEI, yaitu jika pengungkapan intellectual capital berpengaruh negatif pada nilai perusahaan subsektor perbankan yang terdaftar di BEI, yaitu jika pengungkapan intellectual capital meningkat atau bertambah satu satuan maka nilai perusahaan akan mengalami penurunan sebesar 0,001 dengan asumsi variabel lainnya konstan. Nilai koefisien $\beta_{3}=0,078$ menunjukkan bahwa jumlah DKI dari seluruh dewan komisaris dalam perusahaan berpengaruh positif pada nilai perusahaan subsektor perbankan yang terdaftar di BEI, yaitu jika jumlah persentase DKI meningkat atau bertambah satu satuan, maka nilai perusahaan akan meningkat 0,078 dengan asumsi variabel lainnya konstan.

Hasil uji $F$ pada sampel penelitian ini menunjukkan bahwa nilai signifikansi $\mathrm{P}$ value adalah sebesar 0,010 atau lebih kecil dari $\alpha=0,05$. Hasil uji $\mathrm{F}$ ini bermakna bahwa ketiga variabel independen yang digunakan dalam model 
mampu memprediksi atau menjelaskan fenomena nilai perusahaan subsektor perbankan yang terdaftar di BEI periode 2016-2018.

Hasil analisis dari t-test yang telah dihitung dalam aplikasi SPSS pada Tabel 2, variabel $\mathrm{X}_{1}$ atau pengungkapan ERM menghasilkan nilai koefisien regresi positif 0,003 dengan tingkat signifikansi 0,002 lebih kecil dari taraf nyata $\alpha=0,05$. Hal ini berarti bahwa $\mathrm{H}_{0}$ ditolak sedangkan $\mathrm{H}_{1}$ diterima, pengungkapan enterprise risk management $\left(\mathrm{X}_{1}\right)$ berpengaruh pada nilai perusahaan $(\mathrm{Y})$. Hasil penelitian ini konsisten dengan penelitian terdahulu yaitu (Bertinetti et al., 2013), (Abdel-azim \& Abdelmoniem, 2015), (Abdullah et al., 2015), (Devi dkk., 2017) dan sebaliknya hasil penelitian ini bertolak belakang dengan (Agustina \& Baroroh, 2016), (Ardianto \& Rivandi, 2018), (Mariani \& Suryani, 2018), dan (Siregar \& Safitri, 2019). Berpengaruhnya pengungkapan ERM pada nilai perusahaan membuktikan bahwa sesuai dengan teori sinyal, semakin banyak informasi yang diterima investor, khususnya informasi pengungkapan ERM dapat menjadi sinyal positif atau berita baik bagi investor untuk menanamkan dananya di perusahaan. Investor merespon positif berbagai informasi risiko yang diungkapkan meliputi ancaman risiko lingkungan internal, penetapan tujuan perusahaan yang dibuat manajemen puncak, proses indentifikasi kejadian, proses penilaian risiko yang dilakukan pihak manajemen perusahaan, respon atas risiko, kegiatan pengawasan, informasi dan komunikasi, dan pemantauan risiko.

Berdasarkan hasil pengujian statistik t pada Tabel 2, diperoleh hasil bahwa variabel $\mathrm{X}_{2}$ atau pengungkapan intellectual capital menghasilkan nilai koefisien 
regresi negatif 0,001 dengan tingkat signifikansi 0,291 lebih besar dari taraf nyata $\alpha=0,05$. Hal ini membuktikan bahwa $\mathrm{H}_{0}$ diterima sedangkan $\mathrm{H}_{2}$ ditolak, yang berarti pengungkapan intellectual capital $\left(\mathrm{X}_{2}\right)$ tidak berpengaruh pada nilai perusahaan (Y). Hasil penelitian ini sejalan dengan (Mariani \& Suryani, 2018) dan (Siregar \& Safitri, 2019), sebaliknya, hasil pengujian hipotesis kedua ini bertolak belakang dengan hasil penelitian terdahulu yaitu (Devi dkk., 2017) dan (Ardianto \& Rivandi, 2018). Tidak berpengaruhnya pengungkapan IC pada nilai perusahaan kemungkinan disebabkan oleh objek penelitian yang digunakan dalam penelitian ini adalah perusahaan subsektor perbankan, dimana perusahaan perbankan merupakan industri yang diregulasi dengan sangat ketat oleh regulator, sehingga investor tidak menggunakan informasi IC sebagai pertimbangan dalam pengambilan keputusan investasi. Selain itu, ketiadaan pengaruh pada nilai perusahaan kemungkinan juga disebabkan oleh pengukuran variabel pengungkapan IC yang digunakan dalam penelitian ini berfokus pada kuantitas item yang diungkapkan dalam laporan tahunan tanpa mempertimbangkan kelengkapan semua dimensi yang seharusnya diungkapkan. Faktor lain yang kemungkinan menjadi alasan ketiadaan pengaruh informasi IC pada nilai perusahaan adalah inovasi dan teknologi perusahaan yang telah tercatat sahamnya di BEI relatif setara sehingga investor kurang memperhatikan informasi ini.

Berdasarkan hasil pengujian statistik t pada Tabel 2, diperoleh hasil bahwa variabel $\mathrm{X}_{3}$ menghasilkan nilai koefisien regresi positif sebesar 0,078 dengan tingkat signifikansi sebesar 0,307 lebih besar dari taraf nyata $\alpha=0,05$. Hal ini membuktikan bahwa $\mathrm{H}_{0}$ diterima sedangkan $\mathrm{H}_{3}$ ditolak, yang berarti persentase 
DKI $\left(\mathrm{X}_{3}\right)$ tidak berpengaruh pada nilai perusahaan $(\mathrm{Y})$. Hasil uji hipotesis ketiga ini konsisten dengan penelitian terdahulu yaitu (Wulandari \& Budiartha, 2014) dan (Aprianingsih, 2016), sebaliknya, hasil penelitian ini bertolak belakang dengan penelitian (Hariati \& Widya, 2013), (Muryati \& Suardikha, 2014), (Marhaeni \& Yanto, 2015), (Alfinur, 2016), (Tambunan et al., 2017), dan (Handayani, 2017). Ketiadaan pengaruh variabel dewan komisaris independen pada nilai perusahaan kemungkinan disebabkan investor yang lebih mempertimbangkan kompetensi yang dimiliki oleh masing-masing dewan komisaris independen daripada mempertimbangkan status independensinya.

Hasil uji koefisien determinasi menunjukkan perolehan besarnya nilai adjusted $\mathrm{R}^{2}$ adalah sebesar 0,097 . Hal tersebut berarti variabel nilai perusahaan subsektor perbankan yang tercatat di BEI pada tahun 2016-2018 dapat dipengaruhi secara signifikan oleh variabel pengungkapan ERM, pengungkapan IC, dan persentase DKI sebesar 9,7 persen, sedangkan sisanya sebesar 90,3 persen dijelaskan oleh faktor-faktor lainnya.

Impilkasi teoritis dari penelitian ini yaitu hasil penelitian ini dapat memberi tambahan informasi mengenai kajian empiris tentang pengaruh pengungkapan ERM, pengungkapan IC, dan struktur pengelolaan pada nilai perusahaan. Hasil penelitian ini berimplikasi bahwa variabel pengungkapan IC dan struktur pengelolaan yang diproksikan dengan persentase dewan komisaris independen tidak mampu menjadi variabel yang mempengaruhi nilai perusahaan. Kedua variabel tersebut tidak dapat mendukung teori pensinyalan karena 
informasi yang terkandung dalam kedua variabel tersebut tidak mempu menjadi sinyal bagi investor dalam pengambilan keputusan investasi.

Implikasi praktis dari penelitian ini yaitu hasil penelitian ini dapat menunjukkan bahwa pengungkapan IC dan struktur pengelolaan secara empiris tidak dapat dijadikan referensi bagi manajemen perusahaan sebagai informasi yang dapat meningkatkan nilai perusahaan. Sedangkan pengungkapan ERM secara empiris dapat menjadi referensi bagi pihak manajemen perusahaan sebagai informasi nonkeuangan yang dapat meningkatkan nilai perusahaan di mata investor.

\section{SIMPULAN DAN SARAN}

Berdasarkan hasil analisis dan pembahasan, kesimpulan penelitian ini adalah pengungkapan ERM berpengaruh positif pada nilai perusahaan subsektor perbankan yang tercatat di BEI periode 2016-2018. Pengungkapan IC tidak berpengaruh pada nilai perusahaan subsektor perbankan yang tercatat di BEI periode 2016-2018. Struktur pengelolaan perusahaan yang direfleksikan dengan persentase DKI tidak dapat berpengaruh pada nilai perusahaan.

Berdasarkan simpulan penelitian, maka peneliti dapat memberikan saran bagi perusahaan subsektor perbankan agar memahami pentingnya tindakan manajemen risiko untuk diterapkan di perusahaan dan tidakan-tindakan tersebut sebaiknya disampaikan dan diungkapkan kepada pihak stakeholder dalam laporan tahunan perusahaan agar dapat memberikan informasi dan meningkatkan 
transparansi perusahaan. Pihak perusahaan juga sebaiknya memperhatikan informasi modal intelektual yang dimiliki perusahaan cukup dan mampu memberikan dampak positif bagi perusahaan di masa mendatang. Selain itu perusahaan juga sebaiknya memperhatikan dan menyesuaikan jumlah jajaran dewan direksi agar efektif dan efisien demi keberlangsungan usaha perusahaan. Saran bagi pihak investor sebaiknya memperhatikan informasi ninfinansial tanpa mengurangi esensi dari laporan finansial itu sendiri sebagai informasi tambahan bagi investor dalam pengambilan keputusan investasinya. Bagi peneliti selanjutnya untuk dapat mempertimbangkan perluasan sampel penelitian yaitu seluruh perusahaan yang terdaftar di BEI ataupun memperdalam kriteria variabel yang akan diteliti. Peneliti selanjutnya juga perlu menguji hipotesis ini dengan mempertimbangkan kelengkapan dimensi dari masing-masing pengungkapan tidak hanya memperhitungkan kuantitasnya saja. Selain itu peneliti selanjutnya dapat memperhatikan latar belakang dari dewan komisaris independen seperti tingkat pendidikan formal, pengalaman, dan usia.

\section{REFERENSI}

Abdel-azim, M. H., \& Abdelmoniem, Z. (2015). Risk Management and Disclosure and Their Impact on Firm Value: the Case of Egypt. International Journal of Business, Accounting, and Finance, 9(1), 1-14.

Abdullah, M., Shukor, Z. A., Mohamed, Z. M., \& Ahmad, A. (2015). Risk Management Disclosure: A Study on the Effect of Voluntary Risk Management. Journal of Applied Accounting Research, 16(3), 400-432. https://doi.org/10.1108/JAAR-10-2014-0106

ACFE. (2017). Survai Fraud Indonesia 2016. Retrieved from ACFE INDONESIA CHAPTER website: www.acfe-indonesia.or.id 
Agustina, L., \& Baroroh, N. (2016). The Relationship Between Enterprise Risk Management (ERM) And Firm Value Mediated Through The Financial Performance. Review of Integrative Business \& Economics Research, 5(1), 128-138. Retrieved from http://buscompress.com/journal-home.html

Alfinur, A. (2016). Pengaruh Mekanisme Good Corporate Governance (GCG) Terhadap Nilai Perusahaan Pada Perusahaan Yang Listing Di Bei. Jurnal Ekonomi Modernisasi, 12(1), 44-50. https://doi.org/10.21067/jem.v12i1.1178

Aprianingsih, A. (2016). Pengaruh Penerapan Good Corporate Governance, Struktur Kepemilikan, dan Ukuran Perusahaan Terhadap Kinerja Keuangan Perbankan. Jurnal Profita, 4(4), 1-16. Retrieved from https://eprints.uny.ac.id/31985/

Ardianto, D., \& Rivandi, M. (2018). Pengaruh Enterprise Risk Management Disclosure, Intellectual Capital Disclosure dan Struktur Pengelolaan terhadap Nilai Perusahaan. Profita, 11(2), 284-305. https://doi.org/10.22441/profita.2018.v11.02.009

Arifah, E., \& Wirajaya, I. G. A. (2018). Pengaruh Pengungkapan ERM terhadap Nilai Perusahaan dengan Ukuran Perusahaan, Leverage dan Profitabilitas sebagai Variabel Kontrol. E-Jurnal Akuntansi Universitas Udayana, 25(2), 1607-1633. https://doi.org/10.24843/EJA.2018.v25.i02.p30

Ariyanti, F. (2016, November 14). Dalam 2 Tahun, Ada 108 Kasus Kejahatan Perbankan. Liputan6. Retrieved from liputan6.com/bisnis/read/2651413/dalam-2-tahun-ada-108-kasus-kejahatanperbankan

Banjarnahor, D. (2018, April 27). Drama Bank Bukopin: Kartu Kredit Modifikasi dan Rights Issue. CNBC Indonesia.

Bertinetti, G. S., Cavezzali, E., \& Gardenal, G. (2013). The Effect of the Enterprise Risk Management Implementation on the Firm Value of European Companies. In SSRN Electronic Journal (No. 10). https://doi.org/10.2139/ssrn.2326195

Caselli, S., \& Negri, G. (2018). Company Valuation in Private and Venture Capital. In Private Equity and Venture Capital in Europe (2nd ed., pp. 241250). https://doi.org/10.1016/B978-0-12-812254-9.00017-6

Damayanthi, I. G. A. E. (2019). Fenomena Faktor yang Mempengaruhi Nilai Perusahaan. Jurnal Ilmiah Akuntansi Dan Bisnis, 14(2), 208-218. https://doi.org/10.24843/JIAB.2019.v14.i02.p06 
Devi, S., Budiasih, I. G. N., \& Badera, I. D. N. (2017). Pengaruh Pengungkapan Enterprise Risk Management dan Pengungkapan Intellectual Capital terhadap Nilai Perusahaan. Jurnal Akuntansi Dan Keuangan Indonesia, 14(1), 20-45. https://doi.org/10.21002/jaki.2017.02

Dierickx, I., \& Cool, K. (1989). Asset Stock Accumulation and Sustainability of Competitive Advantage. Management Science, 35(12), 1504-1511. https://doi.org/10.1287/mnsc.35.12.1504

Dumay, J. (2016). A Critical Reflection on the Future of Intellectual Capital: From Reporting to Disclosure. Journal of Intellectual Capital, 17(1), 168184. https://doi.org/10.1108/JIC-08-2015-0072

Dumay, J., \& Guthrie, J. (2017). Involuntary Disclosure of Intellectual Capital: Is it Relevant? Journal of Intellectual Capital, 18(1), 29-44. https://doi.org/10.1108/JIC-10-2016-0102

Giacosa, E., Ferraris, A., \& Stefano, B. (2017). Exploring Voluntary External Disclosure of Intellectual Capital in Listed Companies an Integrated Intellectual Capital Disclosure Conceptual Model. Journal of Intellectual Capital, 18(1), 149-169. https://doi.org/10.1108/JIC-01-2016-0019

Hafiyyan. (2018, July 10). Peringkat Asean Corporate Governance, Rangking RI Didorong 5 Emiten. Bisnis.Com, p. 1. Retrieved from https://market.bisnis.com/read/20180710/192/814884/peringkat-aseancorporate-governance -rangking-ri-didorong-5-emite

Handayani, B. D. (2017). Mekanisme Corporate Governance, Enterprise Risk Management, Dan Nilai Perusahaan Perbankan. Jurnal Keuangan Dan Perbankan, 21(1), 70-81. https://doi.org/10.26905/jkdp.v21i1.1228

Hariati, I., \& Widya, Y. (2013). Pengaruh Tata Kelola Perusahaan dan Kinerja Lingkungan terhadap Nilai Perusahaan. Jurnal Ilmiah Mahasiswa FEB Universitas Brawijaya, 3(2), 1689-1699. Retrieved from https://jimfeb.ub.ac.id/index.php/jimfeb/article/view/1847

Hoyt, R. E., \& Liebenberg, A. P. (2011). The Value of Enterprise Risk Management. Journal of Risk and Insurance, 78(4), 795-822. https://doi.org/10.1111/j.1539-6975.2011.01413.x

Jubb, S. N. M. A. C. (2016). Risk Disclosure, Cost of Capital and Performance. International Journal of Accounting \& Information Management, 24(4), 476-494. https://doi.org/10.1108/IJAIM-02-2016-0016

Khumairoh, N. A., \& Agustina, L. (2017). The Roles of The Board of Commissioner in Moderating Factors Affecting The Disclosure of Enterprise 
Risk Management. Accounting Analysis Journal, 6(3), 445-457. https://doi.org/10.15294/aaj.v6i3.18908

Koeswara, A. I., \& Harjito, D. A. (2016). Pengaruh Penerapan Enterprise Risk Management Terhadap Financial Distress dan Nilai Perusahaan. Jurnal Manajemen Bisnis Indonesia, 3(2), 185-198. https://doi.org/10.31843/jmbi.v3i2.79

Lafont, J., Ruiz, F., Gil-gómez, H., \& Oltra-badenes, R. (2020). Value Creation in Listed Companies: A Bibliometric Approach. Journal of Business Research, 115(41), 428-434. https://doi.org/10.1016/j.jbusres.2020.01.012

Lestari, W. (2013). Tinjauan atas PSAK No. 19 (Revisi 2010): Aset tak Berwujud dengan PSAK No. 19 (Revisi 2000). Jurnal Ilmu Ekonomi Dan Sosial, 2(2), $115-128$.

Maingot, M., Quon, T., \& Zeghal, D. (2013). The Disclosure of Enterprise Risk Management (ERM) Information: an Overview of Canadian Regulations for Risk Disclosure. Journal of Governance and Regulation, 2(4), 13-21. https://doi.org/10.22495/jgr_v2_i4_p2

Marhaeni, T., \& Yanto, H. (2015). Determinan Pengungkapan Enterprise Risk Management (ERM) pada Perusahaan Manufaktur. Accounting Analysis Journal, 4(4), 1-22. https://doi.org/https://doi.org/10.15294/aaj.v4i4.9113

Mariani, D., \& Suryani. (2018). Pengaruh Enterprise Risk Management Disclosure, Intellectual Capital Disclosure dan Corporate Social Responsibility Disclosure terhadap Nilai Perusahaan dengan Profitabilitas sebagai Variabel Pemoderasi (Studi Empiris pada Perusahaan Sektor Industri Baran. Jurnal Akuntansi Dan Keuangan, 7(2), 119-138. https://doi.org/ISSN: 22527141

Morris, R. D. (2016). Signalling, Agency Theory and Accounting Policy Choice. Accounting and Business Research, 18(69), 47-56. https://doi.org/10.1080/00014788.1987.9729347

Muryati, N., \& Suardikha, I. (2014). Pengaruh Corporate Governance Pada Nilai Perusahaan. E-Jurnal Akuntansi Universitas Udayana, 9(2), 425-429.

Negara, I. K. (2019). Analisis Pengaruh Good Corporate Gpvernance terhadap Nilai Perusahaan dengan Corporate Social Responsibility sebagai Variabel Pemoderasi (Studi pada Indeks SRI-KEHATI yang Listed di BEI). Jurnal Magister Manajemen Universitas Mataram, 8(1), 46-61. https://doi.org/10.29303/jmm.v8i1.408

Otoritas Jasa Keuangan. (2014). Peraturan Otoritas Jasa Keuangan Nomor 


\begin{abstract}
33/POJK.04/2014 tentang Direksi dan Dewan Komisaris Emiten atau Perusahaan. Retrieved from http://aaui.or.id/wpcontent/uploads/2018/08/POJK-33-2014-DIREKSI-_-DEWANKOMISARIS-EMITEN-ATAU-PERUSAHAAN-PUBLIK.pdf
\end{abstract}

Otoritas Jasa Keuangan. (2016). Peraturan Otoritas Jasa Keuangan Nomor 29/POJK.04/2016 tentang Laporan Tahunan Emiten atau Perusahaan Publik. Retrieved from https://www.ojk.go.id/id/kanal/pasarmodal/regulasi/peraturan-ojk/Documents/Pages/POJK-Laporan-TahunanEmiten-Perusahaan-Publik/POJK-Laporan-Tahunan.pdf

Rahmi, S. N., \& Harnovinsah. (2013). Pengaruh Intellectual Capital Disclosure dan Corporate Governance terhadap Nilai Perusahaan (Studi Empiris pada Perusahaan Manufaktur Terdaftar di BEI). Jurnal TEKUN, 4(02), 264-278.

Sadasiha, Y. G. (2014). Pengaruh Mekanisme Corporate Governance terhadap Kinerja Perusahaan (Studi Empiris pada Perusahaan Property, Real Estate dan Building Construction yang Terdaftar di Bursa Efek Indonesia Tahun 2010-2012). Diponegoro Journal of Accounting, 3(3), 709-723. Retrieved from http://ejournal-s1.undip.ac.id/index.php/accounting

Setiawan, S. R. D. (2016, December 22). "Brexit" hingga Trump, ini Peristiwa Penting Ekonomi Global di 2016. Kompas.Com, p. 1. Retrieved from https://money.kompas.com/read/2016/12/22/070000026/.brexit.hingga.trump .ini.peristiwa.penting .ekonomi.global.di.2016?page=all

Siregar, N. Y., \& Safitri, T. A. (2019). Pengaruh Pengungkapan Enterprise Risk Management, Intellectual Capital, Corporate Social Responsibility, dan Sustainability Report terhadap Nilai Perusahaan. Jurnal Bisnis Darmajaya, 05(02), 53-79. Retrieved from https://jurnal.darmajaya.ac.id/index.php/JurnalBisnis/article/view/1589

Srivastav, N., \& Singh, J. P. (2013). Global Financial Crisis: Corporate Governance Failures and Lessons. Journal of Finance, Accounting and Management, 4(1), 21-34. Retrieved from https://www.questia.com/read/1P3-3243470161/global-financial-crisiscorporate-governance-failures

Syafitri, T., Nuzula, N. F., \& Nurlaily, F. (2018). Pengaruh Good Corporate Governance terhadap Nilai Perusahaan (Studi pada perusahaan industri sub sektor logam dan Sejenisnya yang terdaftar di bei periode 2012-2016). Jurnal Administrasi Bisnis (JAB), 56(1), 118-126. Retrieved from http://administrasibisnis.studentjournal.ub.ac.id/index.php/jab/article/view/23 $27 / 2722$

Tambunan, M. C. S., Saifi, M., \& Hidayat, R. R. (2017). Pengaruh Good 
Corporate Governance terhadap Nilai Perusahaan (Studi pada Perusahaan Sub Sektor Food and Beverages yang Terdaftar di BEI Tahun 2012-2015). Jurnal Administrasi Bisnis (JAB), 53(1), 49-57. Retrieved from http://administrasibisnis.studentjournal.ub.ac.id/index.php/jab/article/view/21 81

Ulum, I. (2015). Intellectual Capital Disclosure: Suatu Analisis dengan Four Way Numerical Coding System. Jurnal Akuntansi \& Auditing Indonesia, 19(1), 39-50. https://doi.org/10.20885/jaai.vol19.iss1.art4

White, G. P., Lee, A., Yuningsih, Y., \& Nielsen, C. (2010). The Nature and Extent of Voluntary Intellectual Capital Disclosures by Australian and UK Biotechnology Companies. Journal of Intellectual Capital, 11(4), 519-536. https://doi.org/10.1108/14691931011085669

World Bank. (2017). Financial Sector Assessment Republic of Indonesia. Finance \& Markets Global Practice East Asia and Pacific Region Vice Presidency, $28 . \quad$ Retrieved from http://documents.worldbank.org/curated/en/104191505745150824/IndonesiaFSAP-Update-

Wulandari, N. P. Y., \& Budiartha, I. K. (2014). Pengaruh Struktur Kepemilikan, Komite Audit, Komisaris Independen dan Dewan Direksi terhadap Integritas Laporan Keuangan. E-Journal Akuntansi Universitas Udayana, 7(3), 574586.

Yopie, S., \& Jurnali, T. (2014). Analisis Pengaruh Tata Kelola Perusahaan dan Efek Pengungkit Keuangan Terhadap Nilai Perusahaan yang Terdaftar di Bursa Efek Indonesia. Journal of Accounting \& Management Research, 09(1), 99-108. Retrieved from https://docplayer.info/55053923-Analisispengaruh-tata-kelola-perusahaan-dan-efek-pengungkit-keuangan-terhadapnilai-perusahaan-yang-terdaftar-di-bursa-efek-indonesia-bei.html 